\title{
Towards a critique on intellectual property
}

\author{
João Romeiro Hermeto \\ https://orcid.org/0000-0002-1053-4175 \\ ${ }^{1}$ Freie Universität Berlin, Institut für Philosophie, Berlin, GER
}

\section{Towards a critique on intellectual property}

Abstract: In order to understand the essence of digital and virtual world relations and their outcomes, as they gain more social relevance in contemporary society, this paper investigates the category of intellectual property not from the prism of the law but rather on philosophical terms. Such philosophical analysis is based on immanent critique. The starting point is the axiomatic notion of modern capitalism, where the categories of property and intellectual property are regarded as two separated entities. Hegel's philosophy of law enables an important reflection on these two categories since, already in its method, it apprehends the contradictions of bourgeoisie society. Accordingly, contrasting reality and Hegel's understanding, a conflict arises within the notion of intellectual property and its praxis under the rule of law. The state appears as a necessity to guarantee and mediate an immanent conflict that arises from the privatization of intellectual property. As an insoluble problem that emerges within such praxis, the present analysis offers an alternative to the paradigm of a split between property and intellectual property. Based on Lukács' non-essentialist-ontology of the social-being, intellectual property is explained through the prisms of labour and cultural development of human thought.

Keywords: Intellectual property. Property. Capitalism. Digitalization. Power relations.

\section{Rumo a uma crítica sobre propriedade intelectual}

Resumo: Para entender a essência das relações mundiais digitais e virtuais e seus resultados, à medida que ganham maior relevância social na sociedade contemporânea, este trabalho investiga a categoria da propriedade intelectual não a partir do prisma da lei, mas sim em termos filosóficos. Tal análise filosófica é baseada na crítica imanente. O ponto de partida é a noção axiomática do capitalismo moderno, onde as categorias de propriedade e propriedade intelectual são consideradas como duas entidades separadas. A filosofia do direito de Hegel possibilita uma importante reflexão sobre essas duas categorias, pois, já em seu método, apreende as contradições da sociedade burguesa. Assim, contrastando a realidade e o entendimento de Hegel, surge um conflito dentro da noção de propriedade intelectual e sua práxis sob o Estado de Direito. O Estado surge como necessidade de garantir e mediar um conflito imanente que decorre da privatização da propriedade intelectual. Como um problema insolúvel que surge dentro dessa práxis, a presente análise oferece uma alternativa ao paradigma de uma divisão entre propriedade e propriedade intelectual. Baseada na não essencialista-ontologia do ser-social de Lukács, a propriedade intelectual se explica através dos prismas do trabalho e do desenvolvimento cultural do pensamento humano.

Palavras-chave: Propriedade intelectual. Propriedade. Capitalismo. Digitalização. Relações de poder.

Received 27.02.2020. Approved 15.03.2020. Revised 06.06.2020.

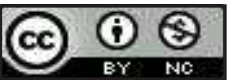

(C) The Author(s). 2020 Open Access This article is distributed under the terms of the Creative Commons Attribution-NonCommercial 4.0 International License (http://creativecommons.org/licenses/by-nc/4.0/), which permits use, distribution, and reproduction in any medium, since it's for non-commercial purposes, and provided you give appropriate credit to the original author(s) and the source, provide a link to the Creative Commons license, and indicate if changes were made. 


\section{Introduction}

In order to understand the essence of digital and virtual world relations and their outcomes, as they gain more social relevance in contemporary society, this paper investigates the category of intellectual property not from the prism of the law but rather on philosophical terms. Such philosophical analysis is based on immanent critique. The starting point is the axiomatic notion of modern capitalism, where the categories of property and intellectual property are regarded as two separated entities. Hegel's philosophy of law enables an important reflection on these two categories since, already in its method, it apprehends the contradictions of bourgeoisie society. Accordingly, contrasting reality and Hegel's understanding, a conflict arises within the notion of intellectual property and its praxis under the rule of law. The state appears as a necessity to guarantee and mediate an immanent conflict that arises from the privatization of intellectual property. As an insoluble problem emerges within such praxis, the present analysis offers an alternative to the paradigm of a split between property and intellectual property. Based on Lukács' non-essentialist-ontology of the social-being, intellectual property is explained through the prisms of labour and cultural development of human thought.

\section{The division of property and intellectual property}

First Thesis: When property and intellectual property are recognized as different entities, an irreconcilable gap emerges between them.

There is no homogeneous notion of property; on the contrary, thinkers from both the same as well as different epochs do not share a common interpretation of what property is. For this reason, it seems impossible to expect a theoretical consensus when interpreting property. Nevertheless, every notion of property also uncovers an underlying political justification.

Different theories and theoreticians not only demand a social understanding of property but also claim a certain right to property use of real resources in order to increase prosperity for their correspondent societies. It is necessarily a question of the means of social production, or of the actual circumstances of life - nonetheless, there is even today plenty of confusion between personal property and property of the means of production, as if they merged.

Plato undertakes an examination of the distribution of goods (mainly of land) and the avoidance of excess of possessions in order to promote the common good. Aristotle presents an idea of private property ${ }^{1}$, the right use of goods to achieve wealth and prosperity. The Roman approach establishes the property right where the property is a direct relationship between man and thing - this relation should be respected and thereby a state of peace can be maintained. Medieval property theory proposes Christian doctrine where the question of claimable use must not be separated from the question of the circumstances of use. John Locke's theory focuses strongly on the contractualism and shapes the appropriation through labour as a justification of property, in clear contrast to the divine view of property of his time. ${ }^{2}$ David Hume and Adam Smith claim a common good that is to be achieved through a relationship between state and market. Immanuel Kant tries to develop a justification of property purely from reason and by doing it he moves away from its real conditions. G.W.F. Hegel, on the other hand, withdraws from pure reason and develops a (private) property theory that not only well adapts to bourgeois social conditions but derives from it. By doing so it claims to express the realization of freedom. On the other hand, Karl Marx portrays private property (of the means of production) as something that instead of promoting freedom represents a hurdle for any possibility of human emancipation - although, historically, the bourgeois conditions of production were not only important but also necessary. John Rawls, in contrast, believes that concerns about relations of production are not relevant but the empowered state should maintain justice in order to promote a common good. Robert Nozick, alternatively, claims that property is an inviolable natural right and should never be touched by the state. Finally, it is also important to emphasize that critical theorists have avoided dealing with this fundamental question of property.

It leaps to the eye that the question of intellectual property was not even mentioned when eluding the category of property. It was Hegel, in his Rechtsphilosophie, who consistently approached property as two categories: property and intellectual property. But to understand such differentiation, one needs to grasp other Hegelian categories, such as law, will, Geist, alienation and freedom. Andreas Eckl points out the merit of Hegel's philosophy of right, which "contributes to the understanding of the interdependencies between law, state and civil society and thus also to political education" (Eckl, 2005, p. 174). For Hegel, the spirit/mind (Geist) is the basis of the law and its starting point is the will, which is free. Therefore, the law is the concretization of this freedom and the world (Welt) of the spirit/mind, "as a second nature" (Hegel, 2013, p. 46). He complements that "[w]ill without freedom is an empty word, just as freedom is only real as a will, as a subject" (Hegel, 2013, p. 46). 


\section{Hegel's categories of property}

For Hegel, thinking is always an appropriation, an object becomes "something that is essentially and directly mine"; only when I make "it into a thought" I perceive that "I am with myself", and he complements, "only comprehension is the piercing of the object that is no longer opposed to me and from which I have taken away that which is mine, which he had against me for himself" (Hegel, 2013, p. 47). The external world is finite, determined; im Geist, it becomes indefinite. However, the will cannot be will if it does not contain an intelligence. The theoretical is part of the (human) being and the "will determines itself" (Hegel, 2013, p. 47); dialectically, as a double negation, Hegel supersedes the differences producing a synthesis of an undetermined determination.

The will is, for Hegel, free in-itself but unfree for-itself, therefore, it requires making an object out of itself to actualize such freedom. It transforms the indefiniteness of the will in a definite. For "[i]n will in general man is infinite, but in thinking he or even reason is limited" (Hegel, 2013, p. 64), He concludes, "a will, which does not decide, is not a real will" (Hegel, 2013, p. 64). The will as a possibility is arbitrary, generic, and, hence, not yet free. According to Robert Pippin, a "free life should be understood as a wholly self-sufficient life, one in which nothing from outside, nothing not-me, determines my actions" (Pippin, 2014, p. 49).

A freedom as an act of the will is, for Hegel, an idea. The notion of idea is, in this sense, not speculative but the actualization of the will. As such, a "being of the free will is [...] a right" (Hegel, 2013, p. 80). The right is "something sacred" because it is the being of the "absolute concept" (Hegel, 2013, p. 83). The development of the idea as an activity of reason "see[s] thinking as subject"; this does not mean to bring reason to the object but the object is for-itself reasonable (Hegel, 2013, pp. 84-85). Geist as the subject becomes predicate, object. Thus, this predicate, transformed into the subject, is itself reasonable and can determine itself; that is, the predicate now becomes not only subject, but the predicate determines the subject and limits it. For the freedom of the object is then called the freedom of human existence. Human existence realizes its freedom from nature through the freedom of things.

According to Hegel, the reason lies beyond man. Property and contract appear, for Hegel, as parts of the abstract right. The ego (Ich), in the form of the singular will, appears as the person. "In personality, therefore, knowledge is its object, but through thinking it is elevated to simple infinity and is thus purely identical with itself" (Hegel, 2013, p. 93). In this sense, individual and person are different categories. While the individual is a spiritual being in- and for-itself only according to the natural will; the object of Geist, as an abstract, a free I, is the person.

According to Joachim Ritter, Hegel's notion of property results from the abstract, bourgeoisie right as the connection of relations of free persons over things as owners (Ritter, 2014, p. 61). The notion of person, property $^{3}$ and freedom appear, insofar, tied together. In order to establish freedom, the person must go beyond the immediate determination of himself and determine the relationship between himself and the thing. "The person must give himself an outer sphere of freedom in order to be as an idea" (Hegel, 2013, p. 102). The thing has now become my predicate. For Hegel, this attachment expresses the determination of the person's immediacy, that is, freedom becomes reality only after an external thing has been taken into possession. The external thing is "a thing, an unfree, impersonal and lawless one" and it is directly different from free spirit; satisfaction of needs does not correspond to the reasonableness of property "but in the fact that the mere subjectivity of personality is abolished"; for Hegel, the person as reason exists "only in property" (Hegel, 2013, p. 102).

To make something mine belongs to natural needs and impulses, it is arbitrary; the possession arises from the free will. And where I objectify myself, I actualize myself. For Hegel, the act of alienation (Entäußerung) is positive and imperative for the realization of the self, which based on legal grounding determinates property, i.e., ownership. In the sense, everything can become the property of the man, because the free will is in- and for-itself.

Intellectual property appears, for Hegel, as "spiritual skills, sciences, arts, even religious things (sermons, masses, prayers, blessings in sacred things), inventions, etc." (Hegel, 2013, p. 104). There arises a fundamental difference between non-intellectual and intellectual property. The spiritual is "certainly inherent in the free spirit," that is, not an external but an internal one; nevertheless, "through manifestation he can give them an external existence and alienate them" (Hegel, 2013, p. 104). The spiritual corresponds to a nature that contains man. Therefore, an important difference to non-intellectual property arises from this relationship. The abstract right contains a freedom that the person acquires because the special thing which has become the object of the law is "inseparable from it and directly different from it" (Hegel, 2013, p. 105). The spiritual things are not to be conceived in the same way, they are already present, they are an inner, immediate part of existence.

The peculiarity of intellectual property consists in its mutability; this peculiarity "may, by the manner in which it is expressed, directly translate into the appearance of a thing" (Hegel, 2013, p. 145). And this is just as important, for what one produces can be now transformed into something else; as others acquire it, they become their immediate owners. But these owners would actually become owners of shared thoughts, i.e., they can "make their own" from what is spiritual/intellectual - be it an invention, a writing, be it any other 
spiritual being (Hegel, 2013, p. 145). Supplementing, Hegel asserts that the spiritual production is spirit, namely a generality in itself. The spiritual [intellectual] production always means to produce something else, even if it is the same because it belongs to general abilities, abilities that cannot be invented.

Stating that property is a means would point to the notion that having property appears in relation to the need; Hegel contradicts this: a property is "end in itself" and freedom arises from it(Hegel, 2013, p. 107). Hegel clarifies his view of private property: "Since in property my will becomes objective to me as a personal will, thus with the will of the individual, it acquires the character of private property" (Hegel, 2013, p. 108). For Max Stirner, who stretches this logic to its extreme, "private property lives by the grace of the law", he continues, "[o]nly in law does it have its guarantee - possession is not yet property" (Stirner, 2012, p. 243). ${ }^{4}$

For Hegel, it is the contract that expresses the real existence of the property and intellectual property, as their existence is also a further concretization of the law. The contract appears as a means of alienation, it represents the concretization of an alienated relationship. ${ }^{5}$ If property is the being of the will, the relationship of wills as the relationship of properties, the free relationship of free wills represents the real freedom of the free will. The contract mediates this relation among diverse wills and various objects.

While Karl Marx asserts that the right to private property is not a question of abstract right but the concretization of real, concrete power of domination from owners of capital over the alien labour, where freedom appears as the freedom to use and exploit others (Marx, 1968, p. 483-484), Axel Honneth considers the positive right to account for the "first institution of freedom in modernity" (Honneth, 2013, p. 134). Insofar, the right of private property appears imperative to create a person self-determined from its free will and not by lust. The critical theorist resembles neoliberal thinkers as he considers the necessity of the subjective rights, as negative freedom, to safeguard individual agencies. Insofar, the state plays not only a crucial role to sustain these social relations based on private property, but it becomes a necessary condition for the realization of capitalist relations.

\section{A twofold separation: an ontology of Geist}

The internal logic of Hegelian thought has in its basis the justification of bourgeoisie institutions, having not only a historical character but also an ontological. Hegel sees the will as the main difference between man and animal, for the latter acts on instinct, while the former on will. The will is negatively conceived as a teleology, as for Hegel an animal cannot conceive what it desires. Furthermore, the will appears as the only source of theoretical behaviour. Insofar, an animal cannot think, while man is active because of thinking (Hegel, 2013, pp. 47, 48).

In his commitment to explain his time, Hegel develops a simultaneously revolutionary and reactionary philosophy. His developed objective idealism is not only full of contradictions, but it is methodologically based on a doctrine of contradiction itself. György Lukács asserts that the "penetrating emergence of contradictions in the presence of his days is thus for Hegel only the culmination of a dialectical process which, starting from inorganic nature, drives life and society to this peak" (Lukács, 1984b, p. 420). Insofar, the contradictions are not elements of immediate reality but rather of thought itself. This postulate becomes apodictic since every confrontation with the real is already itself a product of the mind.

For Hegel, everything is movement but the movement of the idea: ceaseless Prozessualität: a paradox. This means, as an idea, the movement cannot become a process and asserts itself as absolute. The idea does not grasp the real, it presupposes the real as an idea. The real movement becomes the movement of the idea as Marx points out: Hegel "found only the abstract, logic, speculative expression for the movement of history" (Marx, 1981, p. 228). While for Marx this represents a subject-predicate-inversion (Marx, 1981, p. 224), for Hegel is the concept (der Begriff) "the true soul of the world", not as predicate but as "subject" (Hegel, 1986, p. 59). The logic of contradiction, the movement of the idea becomes for Hegel the true motor of reality. The collapse of subject and object into a subject-object-identity bridges the ontological difference between both creating, hence, an absolute in the totality of the concept.

The appealing for Hegel's philosophy, its methodology and ontology, has in its foundation two important dimensions of being themselves revolutionary and reactionary. While most philosophy relegates the ontological, real contradictions which under capitalist relations appear more accentuated, in Hegel they are granted a novel understanding and reflection. This enables a perception - even if hypostasized - of the real movement of nature and society, which with the development of capitalism gains accelerated momentum. Such apprehension not only was, as it still is, revolutionary, since it goes beyond the simplistic apprehensions of non-contradictory logic. Second, his philosophy is also appealing because, while it recognizes the processuality, it resolves contradictions not in reality, as real conflicts, but in thought as a 
synthesis of mutual sublation and preservation: this means, bourgeoisie thinkers find the philosophical basis to forfeiting real - social, political and economic - antagonisms.

The state appears as the perfect expression of this social transformation. It alienates only to be itself alienated. Its monopoly of violence appears not as the so-called state monopoly of violence but rather it mediates the violence of the capitalist dominant class. The state does not mediate conflicts in general but rather specific domination. With its emergence, private property, not as individual possession but rather as separation of the means of production, creates novel forms of social tensions. Insofar, it creates an immediate separation between producer and his means of doing, an external mediation - namely the bourgeoisie state - becomes, therefore, a necessity; otherwise, the producer would directly confront the violence imposed upon his life, his productive life, he would immediately antagonize the owner of the means of production.

The owner, who realizes his existence and freedom in and through private property, is the person. Marx, however, criticizes the notion that the person is the real actualization of the idea:

Hegel describes as abstract the very species-forms [Gattungsgestaltungen] in which the real person realizes his content in actual existence, in which he objectifies himself and abandons the abstraction of the 'person as such'. Instead of recognizing this realization of the person as the most concrete of facts, the state is allegedly distinguished by the fact that in it 'the moment of the concept', 'individuality' achieves a mystical 'existence'. Thus the rational is seen to consist not in the realization of the reason of the real person but in the realization of the moments of the abstract concept. (Marx, 1992, pp. 84-85).

Marx is fully aware that this movement consists in the concretization of relations of power. Insofar, the Hegelian notion that in the property the will asserts itself as free by the cancellation of the arbitrariness of just being a possibility carries in-itself the embryo that cancels Hegel's notion of intellectual property as indefinitely mutable.

As the state guarantee property as private property,

All human culture, all

knowledge is a historical

product of the social-being, its

privatization is ontologically

impossible, its attempt is an

act of domination and violence.

The very notion of a private

intellectual property means

abolishing intellectual property

in-itself, decaying in a less

evolved form of social relation,

where appropriation does not

occur as a teleological setting

but rather as a mere genetical

response to the environment. the law can also impose itself restricting the mutability of intellectual property under patent law and equivalents: as reality proves. Property itself is mutable, a historical product of cultural transformation, an ever-transforming social relation. Land is not property or an acre in-itself, it becomes depending on the social relations. The transformation of land by social relations, or its (theoretically infinite) divisions, constantly creates new social relations and, hence, new contents for the property. If the historical arbitrariness of the law opens the precedent for actualizing relations of power, which in its core contradicts its existence, since law in-itself presupposes the cancellation of arbitrariness, then the law can also prevent the mutability of intellectual property and reframe it only with a determined framework of given relations of power. However, the law can never be law in-itself and for-itself, law cannot be an independent, self-realizing idea, on the contrary, the law is always a product of historical social relations. As such, law is subjected to the singular and collective wants, desires, influences, contradictions, arbitrariness, in summary, to the influence of human agency. From its outset law can never represent the very thing that fundaments its existence: being impersonal, objective; instead it is contradictory, arbitrary and unstable. There is no such thing as the rule of the law but rather the rule of the ruling class, who instrumentalize, weaponize the law to justify its dominance.

Control over intellectual property intends to create an incentive for competition and, hence, an incentive for development, it is, however, a contradiction in-itself, because, if intellectual property, as Hegel sees it, is unique, then the only thing that prevents the nature of intellectual property as a monopoly in-itself to become a monopoly for itself is the absence of law (such as patent, copyrights etc.). Law claims a general benefit of incentivizing competition but in practice, it abolishes it by protecting/creating monopolies. 
While law actualizes relations of power, monopolization of intellectual property is in-itself not the problem that emerges with the law. Its contradictory character lies in deeper social relations. As Adam Smith and Karl Marx well noticed, with capitalism emerges an overwhelming accentuation of the socialization of labour (Marx, 1962; Smith, 2012). Marx goes beyond Smith and identifies in capitalist production the immanent contradiction between cooperation and competition. With the development of forces of production labour becomes increasingly more cooperative with the division of labour, also, science becomes an integrant part of the production. Therefore, the hitherto historical necessity of the existence of private property of production to go beyond both slave-based and feudal societies becomes an impediment for the production and development of social relations. If the relations among (a) producers, (b) producers and consumers and (c) consumers are not immediately determined in their relations but by an external being outside of those spheres - the owner of the means of production -, then the developments of production acquire two existences. First, the owner imposes a phantasmagorical relation to the other dimensions, since the drive of production (teleological setting) subordinates all social relations to the sphere of profit, which appears as an end-in-itself. Second, the social relations, outside from the determination of production of the owner, are estranged from their daily practices and received it as an imposition. The law guarantees such imposition. The real social needs and wants lose, hence, relevance, on the contrary, they appear as an impediment to profit. This capitalist logic incentives neither the production, nor the development, but rather the augmentation of the accumulation of capital. Private property as a barrier to the development manifests it-self not only in the disintegration of the planet or in inequality but also more fundamentally in the very incentives of production, which under imperialistic, financial capitalism tend to cease under monopolistic capitalism (see Lenin, 1971), for instance, the long practices of planned obsolescence, which also reveal the power and coercion that the capital imposes on society while proclaiming freedom, competition and development (see Pope, 2017).

The being of intellectual property as intellectual private property becomes a non-being. If copying, changing, modifying is an act of creation of new intellectual property, then selling it would seem impractical since every appropriation is simultaneously a new creation. Nevertheless, the law guarantees this contradictory movement. "Intellectual property serves to commodify knowledge" (Mueller, 2019, p. 20), and so, transforming it in its negation appears pre-condition for its existence in capitalist society: philosophically, it becomes an insoluble paradox; political-economically, it expresses social tensions, contradictions and domination. On the next section - second part - this ontological problem should become more feasible.

\section{Property and intellectual property as two moments of one totality}

Second Thesis: When property and intellectual property are taken as two moments of the same relation, then their separation and, consequently, their privatization becomes an ontological impossibility.

While, Marx, though acknowledging the "immaterial production" in capitalism, sees little social relevance of intellectual property when compared to "the whole production" and, therefore, it "can stay completely unconsidered" (Marx \& Engels, 1965, pp. 385, 386); as the property is a social relation and its content cannot be defined a priori, as the historical and cultural dimensions played a fundamental role for its practical determination, by still reading Marx a concept stands out, which I propose to use as synonymous of property, and by doing so, making it more palpable. In the introduction to the Grundrisse Marx says: "Every production is the appropriation of nature from the side of an individual within and by means of a determined society. In this sense, it is a tautology to say that property (appropriation) is a condition of production" (Marx, 1983, p. 23). Appropriation neither means nor presupposes a private appropriation. According to Marx, history shows that common property as the former form appropriation, i.e., common appropriation, whereas for Hegel, as shown above, thinking is appropriation. The gap between the two thinkers becomes unbridgeable.

Giving a step back, it emerges the question, if the appropriation is a condition of production, and not mere "thinking", production is a condition of what? Lukács' ontology reveals three categories of nature: inorganic nature, organic nature and the social-being (Lukács, 1984a, p. 8). The essential qualitative difference between inorganic nature and organic nature consists in the fact that to exist organic nature must be produced. Every singular organic being ceases, dies, returns to inorganic nature, however, while production appears as an existential condition for every species of organic nature, it is insufficient. The production of singular beings can only take place within the reproduction of each species. For species has an ontological priority over singular beings.

How does production and reproduction of organic nature relate to appropriation, to the property? 


\section{Labour and the social-being}

While social-being is always part of the organic nature Lukács point out an essential difference between both, namely the form in which social-being produces itself. While the production of life in organic nature appears as a genetic response to its environment, the social-being forms the third ontological category of nature because it produces and reproduces itself in a qualitative completely different form. Labour is the form of human activity that produces and reproduces life by actively shaping its conditions. While producing and reproducing themselves, plants and animals create and transform their environments, the social-being performs this in a peculiar form by conceiving in mind before it acts, the social-being creates its life insofar as a teleological act (Marx, 1962, p. 193). The mere mental construction opens paths to possibilities of unique shaping and handlings but as teleology is always incomplete, it remains immanently possible and impossible. Only the act, or rather the actualization of the teleology as a teleological setting can put into motion what was first conceived in thought. What was thought in-itself becomes with the act - a teleological setting - for-itself, insofar, this real movement creates alternatives hitherto inexistent in nature (Hermeto, 2019, p. 187). The social-being breaks up with the immanency imposed in and by nature. It contains two ontologically novel accents: the simplest creation opens a world of possibilities not only by its immediate use but further unlocks the path to use it as a mediation, as a means for further novelties and, hence, emerging a new set of further possibilities. Sergio Lessa gives a simple but precise example: the creation of an axe opens multiple unforeseeable possibilities for the relations among individuals and its potentialities, between individual and society, and also between social-being and nature (Lessa, 2015, pp. 12-20). The possibilities, however, may not be confused with pre-determinations. There lies by no means a determinism, instead, only subsequent acts and interactions can determine an outcome, which is a latent possibility concretized in new material basis.

This notion of teleology described above may not be confounded with those of Aristoteles and Hegel. While these thinkers grasped the importance of teleology in human relations, they generalized and overstretched it; teleology gains then transcendental characteristics and appears as the motor of history (Lukács, 1986, p. 13). Instead, as Lessa well asserts, "[i]f there is something remarkable about history [...] is that in it events never reoccur" (Lessa, 2015, p. 14), insofar, it cannot be a product of thought but rather a never-ending transformation. If an all-encompassing teleology could indeed produce reality, then the movement of reality (history), the transformation would have to cease, since as product of thought is always abstract, absolute, pre-conceived. Labour, on the contrary, with the actualization of teleology transforms causal relations but never determines its outcome, which remains immanently open.

The separation of property and intellectual property misconceives the ontological character of labour. For labour as a teleological setting is always an appropriation, a transformation in social relation. Nature, for instance, an acre can only become property, if it is conceived as a relation, namely not only by a singular imposition in-itself but rather by a mutual "recognition", a relation for-itself - grounded either on forms of domination, i.e., military, legal, economic power over, or of non-domination. This "recognition" represents an intellectual property, animals "invade" land, houses, industrial plants etc., since they do not recognize property due to the lack of the relation which constitutes the first form of intellectual property. Appropriation - or nonintellectual property -, socially conceived, can only attain its actuality if it becomes in- and for-itself, hence, a moment of intellectual property. Conversely, every intellectual property has no being (Dasein) in- and foritself without property. An individual may have an idea, may compose a song, draft a new invention in his/her head, however, first his head constitutes the materiality that gives concreteness to intellectual property, insofar, intellectual property cannot be in-itself intellectual property, requires a means. As every single being perishes, in order to give a Dasein for-itself to intellectual property, then the intellectual property must surpass the realm of singularity of the brain and gain first an external dimension - either sharing with other brains (stories, songs etc.) or something material (built or written etc.) - and second a historical social dimension, otherwise becomes a private language, thus, unattainable. ${ }^{6}$ Intellectual property and property are always two moments of one relation.

\section{Cultural development of human thought and property as a totality}

To understand this double relation of property and intellectual property, I propose a more fundamental look into cultural development of human thought. For Thomas Nagel, the phenomena of conscious experience "occurs at many levels of animal life", insofar, "that there is something it is like to be that organism" (Nagel, 1974, p. 436). This mode of being a certain organism is, in the sense, existentially understood as a subjective character. 
It is not captured by any of the familiar, recently devised reductive analyses of the mental, for all of them are logically compatible with its absence. It is not analyzable in terms of any explanatory system of functional states or intentional states since these could be ascribed to robots or automata that behaved like people though they experienced nothing. (Nagel, 1974, p. 436).

As seen above, unlikely as often portraited, for instance, consciousness is not what differentiates the social-being from other ontological modes. Michael Pauen underlines that even if the complete understanding of all neuronal characteristics of an organism capable of consciousness is achieved, then all these understandings could never award us access to the immediate consciousness of such being (Pauen, 2005, p. 176). Michael Tomasello asserts: "In some animal species, the developing organism absorbs information not only from its physical but also from its social environment, or from parts of its physical environment that have been significantly altered by its conspecifics" (Tomasello, 2006, pp. 25-26). The cultural evolution of the social-being is a cumulative evolution and such praxis determines and modifies its consciousness. For this process of cultural accumulation evolution, according to Tomasello, "can be understood as a particularly effective form of collective inventiveness or sociogenesis" (Tomasello, 2006, p. 58). This means labour is not only the means for immediate production and reproduction of the social-being but rather an inter-generational-nexus or what Tomasello calls virtual collective. This is the basis for the development of one of the most important organs of the social-being, namely a solely cultural organ: the language (Engels, 1975, p. 446). It arises from social interactions (Tomasello, 2006, p. 265) and, therefore, Marx asserts:

The 'Geist' has from the outset the curse itself of being 'afflicted' with matter, which appears here in the form of moving layers of air, sounds, in short, language. Language is as old as consciousness - language is the practical, real consciousness, which also exists for other people, and thus also for myself, and language, like consciousness, arises only from the need, the need to have intercourse with other people. (Marx \& Engels, 1978, p. 30).

All human culture, all knowledge is a historical product of the social-being, its privatization is ontologically impossible, its attempt is an act of domination and violence. The very notion of a private intellectual property means abolishing intellectual property in-itself, decaying in a less evolved form of social relation, where appropriation does not occur as a teleological setting but rather as a mere genetical response to the environment. Taking again the language as an example, according to Wittgenstein's Philosophical Investigation words have no meaning in-themselves (Wittgenstein, 1967, p. 20, § 40), the emergence of a private language would be impossible because "the meaning of a word is its use in the language" (Wittgenstein, 1967, p. 20, § 43). Words without meaning, without a practical existence are sterile. Such practice is always social, it presupposes the reproduction within the species, namely the social-being.

With the rising of "digital economy", with the increase of the significance of the private intellectual property in modern society, one could use the example of the real economy to contradict the present analyses, this would mean, however, being fixed at the mere phenomenological level of social relations - at the appearance - while ignoring their core. As capitalism contradiction between the socialization of labour and privatization of means of production intensifies, as the mass of capital expands and, for this reason, the rate of the capitalist accumulation faces its tendency to fall, the capitalist class - which has the means of imperialism, of neocolonialism, of state-socialism for corporations and banks, of tax evasion, of money laundering, of financial capital control - tries to overcome this problem, since without appropriating surplus-labour and overshooting it as capital - as an end in itself -, it ceases to be capitalist. The development myths of modern companies, such as Apple, Microsoft, Google, Amazon, PayPal, Tesla, become more preposterous as research has shown that their success is based not only in the socialization of specific labour of their labour-force and production chain but foremost in the entire socialization of resources of US-American society that have been redirected towards state-funded research with no commitment to make profits.

The assumption that the public sector can at best incentivize private sector-led innovation (through subsidies, tax reductions, carbon pricing, technical standards and so on), especially but not only in the face of the recent crisis, fails to account for the many examples in which the leading entrepreneurial force came from the State rather than from the private sector. (Mazzucato, 2013, p. 207).

The example from Mariana Mazzucato with the tech-company Apple is obliterating, since it, one of the most "valuable" companies in the world, owns its success due to many decades of state founded research as an extensive socialization of losses opening the path for private appropriation and private gain. "To understand the fundamental role of the State in taking on the risks present in modern capitalism, it is important to recognize the 
'collective' character of innovation." (Mazzucato, 2013, p. 207) As every year billions of dollars of taxpayer money flows to the US-military complex (National security: 2020 Budget Fact Sheet, 2020), to NASA and other state companies and institutions, it is "unrealistic to think that the highly capital-intensive and high-risk areas in clean technology will be 'led' by venture capital, or 'nudged' by a small and unstructured green investment bank" (Mazzucato, 2013, p. 210). As the fundamental contradiction of capital, namely the social character of production and private character of its appropriation, expands, the usage of the state by the elite to avoid addressing this social, political and economic problem also intensifies social tensions. The violent character of such mediation becomes ever more latent as the leading capitalist society of the world disintegrates (see Hedges, 2018).

\section{Final considerations}

In this paper, I tried to examine the intellectual property, first, in its phenomenological form, namely the separation between property and intellectual property and the privatization of both as justification for social development; and second, in its essence, namely as a social relation that is an integral part not only of labour and the relations of production but also of the cultural development and accumulation.

The bourgeoisie divorce of property and intellectual property accounts for specific relations of power, which, on the one hand, grants the owner of the means of production control over the non-owners and, on the other, produces an insuperable contradiction between both categories, which is expressed in and as social tensions. The division of both categories, though being real, which law establishes and guarantees, cannot surpasses the ontological dimension of property and intellectual property, which can never exist without the immediate existence of each other. Insofar, despite the fact that law separates both categories, they appear ontologically as two moments of the same relation. While the capitalist rhetoric justifies patents, copyrights etc. based on the claim to be safeguarding innovation and competition, in reality, these forms of relations foster and preserve monopolies. With the historical advent, and further with the development, of capitalism, labour becomes incessantly more collective, the private property of the means of production loses its historical importance of agglutinating and commanding labour, instead, it becomes an impediment for further development. The privatization of intellectual property instead of enabling social development appears, consequently, as its immanent constrain, a mere form of securing anachronic relations of power.

\section{References}

Eckl, A. (2005). Der Begriff „Eigentum” in der Rechtsphilosophie Hegels. Was ist Eigentum? München: C. H. Beck.

Engels, F. (1975). Dialektik der Natur. MEW Band 20. Berlin Dietz: Verlag Berlin.

Hayek, F. A. von. (2005). Die Verfassung der Freiheit. Tübingen: Mohr Siebeck.

Hedges, C. (2018). America: The Farewell Tour. New York, London, Toronto, Sydney, New Delhi: Simon \& Schuster.

Hegel, G. W. F. (1986). Enzyklopädie der philosophischen Wissenschaften im Grundrisse - Zweiter Teil: Die Naturphilosophie. Frankfurt am Main: Suhrkamp.

Hegel, G. W. F. (2013). Grundlinien der Philosophie des Rechts oder Naturrecht und Staatswissenschaft im Grundrisse. Frankfurt am Main: Suhrkamp.

Hermeto, J. R. (2019). Lukács' Ontologie des gesellschaftlichen Wandels: Von einer mythologischen Ontologie des absoluten Geistes zu einer Ontologie des gesellschaftlichen Seins. Universität Witten/Herdecke.

Hermeto, J. R. (2020). Subject-predicate-inversion of Gender-neutral-language: An emancipatory confusion. In: Journal of Gender and Power. Vol. 12, n. 1.

Honneth, A. (2013). Das Recht der Freiheit. Berlin: Suhrkamp.

Lenin, W. I. (1971). Lenin Werke 22. Berlin: Dietz Verlag Berlin.

Lessa, S. (2015). Para compreender a Ontologia de Lukács. São Paulo: Instituto Lukács.

Lukács, G. (1984a). Prolegomena zur Ontologie des gesellschaftlichen Seins. Zur Ontologie des gesellschaftlichen Seins, Band 1. Darmstadt, Neuwied: Luchterhand.

Lukács, G. (1984b). Zur Ontologie des gesellschaftlichen Seins, Band 1. Darmstadt, Neuwied: Luchterhand.

Lukács, G. (1986). Zur Ontologie des gesellschaftlichen Seins, Band 2. Sein. Darmstadt, Neuwied: Luchterhand.

Marx, K. (1962). Das Kapital: Kritik der politischen Ökonomie: Erster Band: Buch I: Der Produktionsprozeß des Kapitals. MEW Band 23. Berlin: Dietz Verlag Berlin.

Marx, K. (1968). Ökonomisch-philosophische Manuskripte aus dem Jahre 1844. MEW Band 40. Berlin: Dietz Verlag Berlin.

Marx, K. (1981). Zur Kritik der Hegelschen Rechtsphilosophie. MEW Band 1. Berlin: Dietz Verlag Berlin.

Marx, K. (1983). Einleitung zu den „Grundrissen der Kritik der politischen Ökonomie”. MEW Band 42. Berlin: Dietz Verlag Berlin. 
Marx, K. (1992). Early Writings. London: Penguin Books.

Marx, K., \& Engels, F. (1965). MEW Band 26.1. Berlin: Dietz Verlag Berlin.

Marx, K., \& Engels, F. (1978). Die deutsche Ideologie: Kritik der neuesten deutschen Philosophie in ihren Repräsentanten Feuerbach, B. Bauer und Stirner, und des deutschen Sozialismus in seinen verschiedenen Propheten. MEW Band 3. Berlin: Dietz Verlag Berlin.

Mazzucato, M. (2013). The Entreprenaurial State: Debunking Public vs Private Sector Myths. London, New York, Delhi: Anthem Press.

Mueller, G. (2019). Media Piracy in the Cultural Economy. Media Piracy in the Cultural Economy. New York, London: Routledge Focus. Nagel, T. (1974). What Is It Like to Be a Bat? The Philosophical Review, 83(4), 435-450.

National security: 2020 Budget Fact Sheet. (2020). The White House. Washington DC.

Pauen, M. (2005). Grundprobleme der Philosophie des Geistes: Eine Einführung (4th Aufl.). Fischer Taschenbuch Verlag.

Pippin, R. (2014). Hegel, Freedom, The Will. The Philosophiy of Right (§§ 1-33). In: L. Siep (Hrsg.), G.W.F. Hegel: Grundlinien der Philosophie des Rechts. Berlin: Akademie Verlag.

Pope, K. (2017). Understanding Planned Obsolescence: Unsustainability Through Production, Consumption and Waste Generation. London: Kogan.

Ritter, J. (2014). Person und Eigentum. Zu Hegels Grundlinien der Philosophie des Rechts (§§ 34-81). In: G.W.F. Hegel: Grundlinien der Philosophie des Rechts. Berlin: Akademie Verlag.

Smith, A. (2012). An Inquiry into the Nature and Causes of the Wealth of Nations. Hertfordshire: Wordsworth Editions.

Stirner, M. (2012). Der Einzige und sein Eigentum. Hamburg: Tredition Classics.

Tomasello, M. (2006). Die kulturelle Entwicklung des menschlichen Denkens: Zur Evolution der Kognition. Frankfurt am Main: Suhrkamp.

Wittgenstein, L. (1967). Philosophical Investigations. Oxford: Basil Blackwell.

\section{Notas}

1 Not in the modern sense of private property, where a separation between producer and means of production arises.

2 Locke arbitrarily defines labour insofar it excludes labour from native justifying appropriation by colonization.

3 In German, property is differentiated between ownership, Eigentum, and possession, Besitz; in this sense, they cannot be used as synonyms.

4 This notion achieves its peak with neoliberal capitalism, where the commodification of life is sustained by a complete submission to the so-called "rule of the law" as Friedrich von Hayek blindly praised in what I called his dialectic of freedom, where state coercion is coercion, capitalist market coercion is freedom (see the chapter „Freiheit und Gesetz” (Freedom and Law), Hayek, 2005).

5 This is not the Marxist alienation (Entäußerung) that can often be confused with Marx' estrangement (Entfremdung).

6 For the impossibility of private language see below arguments regarding Wittgenstein's Philosophical-Investigations (Wittgenstein, 1967); see also (Hermeto, 2020).

\section{João Romeiro Hermeto}

joaoromeirohermeto@gmail.com

$\mathrm{PhD}$ in philosophy by Universität Witten/Herdecke (Germany)

Postdoctoral candidate at Freie Universität Berlin (Germany)

\section{Freie Universität Berlin}

Habelschwerdter Allee, 30

Berlin, Germany

CEP: 14195

\section{Acknowledgement}

Not applicable.

\section{Financial support}

Not applicable.

\section{Contributions of authors}

Not applicable.

\author{
Approval by the Ethical Committee and consent to \\ participate \\ Not applicable. \\ Consent to publish \\ Author's consente. \\ Conflict of interest \\ Not applicable.
}

